\title{
THE IMPROVEMENT OF THE OHIO RIVER
}

\author{
By John L. VANCE, \\ President Ohio Valley Improvement Association, Columbus, $\mathrm{O}$.
}

In a discussion of the improvement of the Ohio river, it will not be inappropriate to state at the outset the claims on which the six Ohio river states-Pennsylvania, West Virginia, Ohio, Kentucky, Indiana and Illinois-base their demands upon the general government for the canalization of the river from Pittsburg to its junction with the Mississippi at Cairo, a distance of one thousand miles as the stream meanders. The Ohio alone, of all navigable rivers in the United States, carries tonnage from its source to its mouth. It drains the richest valley in the civilized world; and the river might be of the greatest possible benefit not alone to the commercial, manufacturing, mining and agricultural industries of the six states, but of the greatest possible value to the trade and commerce of the United States, and, unquestionably, the greatest of all feeders to the Panama Canal.

The manufactures of Pennsylvania, West Virginia, Ohio, Kentucky, Indiana and Illinois, in I905, amounted to $\$ 4,979,453,665$ in value. Of that total Pennsylvania contributed $\$ 1,955,551,332$; Illinois, \$1,410,342,129; Ohio, \$960,81 r,857; Kentucky, \$159,753,966; Indiana, $\$ 393,954,305$; and West Virginia, $\$ 99,040,076$. The three crops of corn, wheat and hay were of the total farm value of $\$ 646$,090,621 , with other crops in proportion. The wealth of the six states was $\$ 25,941,897,242$, distributed as follows: Pennsylvania, $\$ 9,315$, 140, 1 16; Illinois, $\$ 6,976,476,400$; Ohio, $\$ 5,019,004,453$; Indiana, $\$ 2$,$606,493,004$; Kentucky, $\$ 1,365,130,718$; and West Virginia, $\$ 659$,652,551 . The total wealth of the United States was $\$ 88,517,306,775$; the six Ohio river states contain approximately one-third of the entire wealth of the country, while the remaining members of the Union, forty states and territories, contributed the remaining twothirds.

During the fiscal year ending June 30,1905 , according to the report of the Commissioner of Internal Revenue, the six Ohio river states paid into the Federal treasury not only one full half of all 
internal revenue collected, but $\$ 16,000,000$ in excess of that full half.

Such are the Ohio river states, which are demanding the canalization of the Ohio from Pittsburg to Cairo to a depth of nine feet. It is a demand made in the interests not alone of their trade and commerce but in the name of the trade and commerce of the entire country. It is a demand, primarily, it is true, of the Ohio river states-for they furnish the coal for the markets of the South; the coal and the natural gas that heats the furnaces and supplies the forges; that lights and heats the schools, the churches, and the dwellings. They produce the salt, the fire clay, the timber, the ores. They manufacture the pottery, the steel rails, the structural iron and steel, and finished glass and wood products of the country. They stand at the doors of the government confident in the justice of their demands, and in the knowledge that the benefit to them would be of immeasurable benefit to their sister states, especially to those of the great valleys between the Rockies and the Appalachian ranges, but also of immeasurable value to the trade and the commerce of all other sections of the country.

As early as 1804 the legislature of Kentucky incorporated the company organized for the purpose of constructing the Louisville and Portland Canal, with a capital stock of $\$ 600,000$, for the purpose of aiding navigation by avoiding the falls of the Ohio at Louisville. Of the capital stock, 3,665 shares of the par value of $\$ 100$ were held by the citizens of New Hampshire, Massachusetts, New York, Pennsylvania, Maryland, Missouri and Kentucky, with the Federal Government holding 2,333 shares. Although contracts were soon let for the work, it was not begun until 1825, and not until December, 1830, was the canal opened for navigation. During the first twelve months of its operation 406 steamboats and 375 flatboats, with an aggregate tonnage of 76,323 tons, passed through the canal, while for the month of July, 1907, the tonnage passing through the canal on steamers and barges was $1,100,533$ tons. For the corresponding month of 1906 there were 805,672 tons. The canal was originally under state control, but is now under the control of the Federal Government.

About 1825 Colonel Long, of the engineer corps, in charge of the improvement of the Ohio, put into execution his plan of constructing wing dams, instead of the older plan of cutting channels 
through sand-bars and shoals, and of that work Hall" says: "To cut a channel through a bank of sand would not be impracticable, but the excavation thus made would be filled up by the deposits of the next flood. About ten years ago Colonel Long, of the topographical engineers, was instructed by the government to make an experiment, and adopted the plan of throwing out wing dams from each side of the river, so as to confine the current within narrow bounds and to give sufficient volume to wash a channel for itself. He spent one summer in constructing such a work at Henderson, 200 miles below Louisville. The dams were constructed of piles driven into the sand and rising but a few inches above the surface. Not a trace of the work of Colonel Long remains to-day, and Hall well says that "the objection to any of these measures is that they have not been attempted on a scale of magnitude becoming their importance, and urged with all the energy becoming a great nation."

Wing dams were constructed at many points along the river. But experience demonstrated that they would not furnish the relief sought-would not maintain a sufficient stage of water to meet the demands of commerce. Dredge boats were brought into service, but they were found to be unavailing. Hence, the work of improving the Ohio languished. For many years the efforts in its behalf were sporadic and confined to local necessities, real or fancied. The sneer of Randolph, of Roanoke, that the Ohio was a stream which was dried up during six months of the year and frozen over curing the other six months, together with "pork barrel" insinuations, not only stayed the improvement of the Ohio, but of all rivers. The coming of the railroad added to the neglect with which the Ohio, the greatest tonnage-bearing stream in the United States, was treated.

One important enterprise, however, was undertaken-the building of a lock and movable dam at Davis Island, about five and a half miles below Pittsburg. This dam was undertaken and completed for the purpose of furnishing a pool six feet in depth, in which towboats and barges might find safe harbor and be ready to take advantage of a "coal boat rise" and move down the river to the markets on the Ohio and the Mississippi. But this improvement was made in a half-hearted way, and with no belief that it would become

\footnotetext{
I "Statistios of West Cincinnati," 1836.
} 
one in a chain of similar locks and movable dams that, when built along the river's entire length, would give a permanent and reliable depth of nine feet of water throughout the year. Appropriations for the Davis Island dam were slow; the work was prosecuted without energy. Finally, when completed, it was found to work successfully; the pool was formed, and the advantage of even this beginning of something "permanent" exceeded all expectations; but with the completion of this lock and movable dam, permanent efforts to improve the river practically ceased.

Whether it was because of the total inadequacy of the railroad as a means of transportation, or whether it was because of an awakening of the Ohio Valley to the immeasurable capacities of the Ohio river as a tonnage bearer is immaterial to the present purpose; the awakening came, resulting in the organization of the Ohio Valley Improvement Association, at Cincinnati, in 1895. Since that time there has been persistent and successful effort for the permanent improvement of the river to a nine-foot stage from Pittsburg to Cairo by a series of locks and movable dams.

At the first meeting of the association there were delegates present representing the mining, manufacturing, commercial, agricultural and the river interests of the Ohio Valley. They were men who fully realized that the permanent improvement of the Ohio to a navigable stage ample for the largest boats was imperatively demanded by every community and interest in the Ohio and Mississippi Valleys. The association has grown in numbers and in influence with the passing of every year. Annual conventions have been held regularly at important places along the river, the last one at Wheeling, W. Va., on the I4th and I $5^{\text {th }}$ of November, 1907.

The association at first was of the opinion that a six-foot stage would be sufficient; but experience demonstrated otherwise, and in 1902 the nine-foot stage became the platform of the association. It is gratifying to be able to state that the nine-foot stage has been accepted as the true standard of improvement of the Ohio, and the Congress of the United States is now irrevocably committed to it.

I have said that the Ohio is unique in the fact that it is the only stream carrying tonnage from its source to its mouth. It not only carries tonnage from its source to its mouth, but it supplies almost wholly the tonnage on the Misissippi from Cairo to New Orleans, for on the great Mississippi to-day there is no packet ply- 
ing between St. Louis and New Orleans, nor any between Memphis and New Orleans, save the packets that steam out of the Ohio into the Mississippi.

Of the work that has been done for the permanent improvement of the Ohio since the organization of the Ohio Valley Improvement Association in I895, only a brief summary can be given. The first important action by Congress was an appropriation for the survey and fixing of sites for locks and movable dams from Pittsburg to the mouth of the Muskingum river. This was followed by a survey of like character from the mouth of the Muskingum to the mouth of the Big Miami. By these two surveys it was found necessary to construct and sites were fixed for thirty-seven locks and movable dams.

On this stretch of river, covering about one-half its entire length, appropriations have been made for the prosecution of the work on more than one-third of the locks and dams. The first six, immediately below Pittsburg, including Davis Island dam, are practically completed; locks and dams numbered 8, II, I3, 18 and 37 are nearing completion; land for locks and dams numbered 7 and 19 has been secured, and partial appropriation for work on 19 has been made; full appropriation $(\$ 1,200,000)$, cash and contract, has been made for No. 26, below the mouth of the Great Kanawha and Gallipolis, and the engineers are now engaged in final surveys to fix the exact location. The locks and dams named, below No. 6, were provided for by reason of the fact that they were considered of first importance. With the completion of No. 37 (about ten miles below Cincinnati) a harbor nearly thirty miles in length will be made, which will be of supreme importance to Cincinnati and her large interests. When No. 26 is completed the product of the coal fields of the Kanawha Valley may be transported to the markets of the Ohio Valley regularly by lowering the wickets on the Kanawha River and those of Nos. 26 and 37, thus flushing the river and giving the required water.

By direction of Congress the survey of the Ohio was completed from the mouth of the Big Miami to Cairo by a board of United States engineers composed of Lieutenant-Colonels Lockwood, Sears and Ruffner, and Majors Zinn and Sibert. Statistics of the tonnage of the Ohio were collected and tabulated at the request of the board, by the Ohio Valley Improvement Association. 
The report of this board was filed in the War Department on the 4th of January, 1907, and was referred to the board of engineers for rivers and harbors, commonly known as the board of review. The report will no doubt be presented to Congress at its approaching session.

It is probable that the greatest work accomplished by the Ohio Valley Improvement Association was in its invitation to the Committee on Rivers and Harbors of the House of Representatives to make a tour of the Ohio from Pittsburg to Cairo on the steamer Queen City, commanded by Captain J. F. Ellison, secretary of the association and also secretary of the National Rivers and Harbors Congress. The trip was made in daylight, and covered ten days. That the tour was a source of the most valuable information to the committee is undoubted, and the fact was fully and most cordially conceded by all of the number. That it was productive of great good to the work in which the association is engaged is equally undoubted. The committee saw, from source to mouth, a magnificent river $\mathrm{I}, \mathrm{OOO}$ miles in length, with steamers not only passing down stream laden with merchandise, but steamers alone, and with barges coming from local ports and from New Orleans and other southern points loaded with sugar, molasses, cotton, lumber or material for pulp mills-a stream on which coal and iron and other heavy products are carried at the phenomenally low rate of one-third of a mill per ton per mile; a stream on the banks of which, from Pittsburg to Cairo, there was an endless panorama of mining and manufacturing operations; a valley than which none is richer in agricultural products in the United States. They saw a stream which, during the fiscal year ending June 30 , 1906, carried-according to official reports-more than 4,500,000 passengers and more than $x_{5}, 000,000$ tons of freight; a river on whose waters, not always navigable in their unimproved state, the steamer Sprague, the leviathan of western waters, took in safety from Pittsburg to Cairo, and from Cairo to New Orleans, in one tow of coal, no less than 70,000 tons-a tow of freight which would require not less than 2,333 coal cars, making a train fifteen miles in length, not including the locomotive engines required to draw it. They saw a river which, more than any other river in the country, has demonstrated that it is not present tonnage carried that determines its merits or its standing before the Committee on Rivers and Harbors 
of the House, but that it is the tonnage-bearing capacity of a stream improved that determines its standing.

The benefits that have come with the completion of each lock and movable dam on the Ohio accrue to every mine and factory in the valley. With the completion of the nine-foot stage from Pittsburg to Cairo, the valley of the Ohio-the very heart of the commercial and industrial life of the country-would not depend solely on railroads for transporting the ores from the mines nor on the finished product from the factories to the markets. To-day the merchant, the farmer, the manufacturer, and the miner find the value of their products at zero too often because of inability of the railway to furnish him transportation to a market-for the value of the article of commerce is measured by its ability to reach a market. With the Ohio permanently improved, merchant and manufacturer, miner and farmer, would have ready access at all seasons of the year to a market, and the consumer would profit none the less than the producer. 